\title{
VEGETATION CHANGE IN ROAD SLOPES IN THE MEDITERRANEAN REGION OVER 25 YEARS
}

\author{
Álvaro ENRÍQUEZ-de-SALAMANCA (1D) 1, 2, 3* \\ ${ }^{1}$ Department of Biodiversity, Ecology and Evolution, Complutense University of Madrid, \\ José Antonio Novais, 12, 28040 Madrid, Spain \\ ${ }^{2}$ Science Faculty, National University of Distance Education (UNED), Madrid, Spain \\ ${ }^{3}$ Draba Environmental Engineering \& Consulting, San Lorenzo de El Escorial, Spain
}

Received 17 August 2020; accepted 30 June 2021

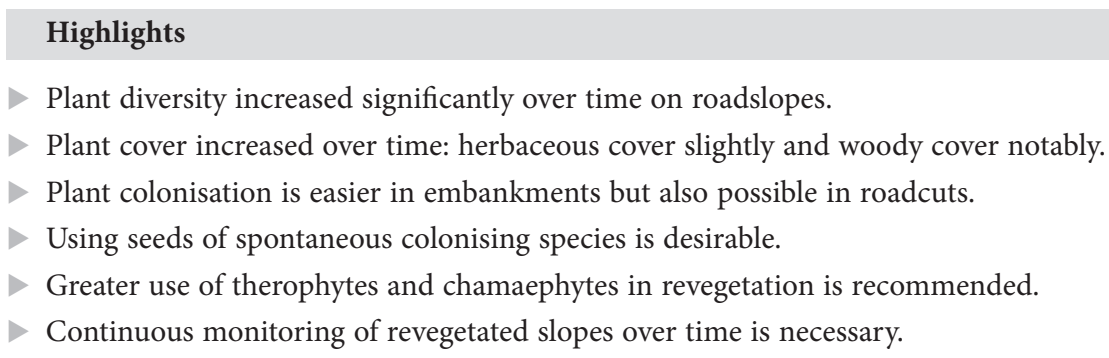

\begin{abstract}
Revegetation effectiveness requires long-term monitoring. We analysed 50 road slopes 5-8 years and 22-25 years after revegetation. Plant cover and diversity increased over time, with differences between slope types; herbaceous cover increased greatly between revegetation works and 2002 and was similar in 2002 and 2019, while woody cover decreased from revegetation to 2002 but increased greatly between 2002 and 2019. Plant colonisation was more intense on embankments, but could also be achieved on roadcuts (2.4 points on average over a maximum of 5 ). The presence of sown species decreased over time, but the presence of planted species remained stable. Hydroseeding had poor results in terms of the resulting plant cover, but nevertheless succeeded in slowing erosion at least sufficiently to allow early plant establishment and thus the start of colonisation. The similarity between surrounding vegetation and the slopes was greater in roadcuts. Roads are a gateway for invasive plants. Native species can improve the results, but many are missing from the market. Slopes' plant cover changed over time; long-term studies are required.
\end{abstract}

Keywords: roadcuts, embankments, plant colonisation, hydroseeding, topsoil, planting.

Online supplementary material: Supporting information for this paper is available as online supplementary material at https://doi.org/10.3846/jeelm.2022.16324

\section{Introduction}

Road construction requires the formation of cut and embankment slopes, to adapt the platforms to the terrain. These slopes, where the soil is bare, generate visual impacts and are subject to intense erosion, so revegetation is highly recommended.

Revegetation objectives may be restoration, trying to return to the pre-existing state, or rehabilitation, seeking an alternative steady state (Aronson et al., 1993), depending on location and alteration. Frequently revegetation focus on aesthetic criteria; however, the key short-term objective in road slopes should be to stop erosion when exists. Slope erosion depends on different factors such as angle, geology, water circulation and vegetation cover, mainly herbaceous; it is severe when herbaceous cover is under 25\% (Andrés \& Jorba, 2000). After the construction of a road, the slopes are highly exposed to erosion, which is reduced and stabilised over time; in the first year, sediment yield is much higher than in the subsequent years (Navarro-Hevia et al., 2016). When a slope suffers erosion, soil formation processes are very slow, water availability is

${ }^{*}$ Corresponding author. E-mail: aenriquez@draba.org 
reduced exponentially (Nicolau et al., 2011) and there is a constant drag of the seeds that reach the slopes' surface, all factors that make colonisation difficult. When a rapid initial colonisation is achieved, even of annual herbs, surface erosion is reduced and seed retention favoured, allowing a progressive development of plant communities; erosion rates are significantly reduced with vegetative covers between $30-50 \%$ (Nicolau et al., 2011). In early stages pioneer vegetation depends on dispersal capacity, while over time soil properties have greater influence (Walker \& del Moral, 2009). Consequently, restoration should focus on favouring an early plant establishment (Roberts \& Bradshaw, 1985), and after on preserving the vegetation cover (Jiménez et al., 2013).

Several factors influenced plant colonisation on slopes, such as slope type, angle, geology, compactness, rockiness, orientation or surrounding vegetation. Roadcuts are formed by excavation, leaving compact and bare soils, steeper than surrounding areas, where vegetation growth is difficult; embankments, however, are banks of soil, less compact and steep, with higher water availability and higher levels of organic matter, assimilable phosphorus and nitrogen (Bochet \& García-Fayos, 2004; Bochet et al., 2010b). As a result, plant colonisation is easier in embankments (Bochet et al., 2011). Slope conditions are different to the surrounding areas, and this affects plant colonisation and development; they are novel ecosystems (Hobbs et al., 2009).

Road slope revegetation did not become a common practice in Spain until the mid-1990s, during the development of most of the high-capacity road network. The first studies about slope revegetation were conducted by three governmental centres, CREAF (Andrés \& Jorba, 2000), CEDEX (Enríquez-de-Salamanca et al., 2002, 2004) and CCMA (Matesanz et al., 2006). After that, more studies were conducted (Table 1), most of them short-term ( 1 or 2 years), often collaborations between construction companies and universities. Navarro-Hevia et al. (2016) conducted a research over 12 years, although focusing on quantifying soil erosion and sediment yield on road slopes and not specifically on revegetation. The fall in road construction since 2008 led to the abandonment of most of these studies, although a few years later a technical and scientific compilation of knowledge on ecological restoration of areas affected by transport infrastructures was published (Valladares et al., 2011). There is a lack of long-term studies in Spain, compared to those undertaken in other countries, such as work by Raevel et al. (2013) in France.

The best way to analyse plant colonisation and succession processes is through direct observation over time (Walker \& del Moral, 2009); monitoring is essential to assess ecological restoration (Bakker et al., 2000). Existing studies on slope revegetation provide informative results, but only in short-term periods.

The aim of this study is to analyse the changes in the vegetation of a sample of road slopes over time, from their revegetation and after 5-8 and 22-25 years. The main questions to be answered are how the vegetation cover, herbaceous and woody, has changed, what is the persistence of the species used in the revegetation and how the

Table 1. Studies about road slope revegetation in Spain

\begin{tabular}{|c|c|c|c|c|c|c|}
\hline \multirow{2}{*}{ Road section } & \multicolumn{2}{|c|}{ Revegetation works } & \multicolumn{3}{|c|}{ Study characteristics } & \multirow{2}{*}{$\operatorname{Ref}^{c}$} \\
\hline & Year & Time to study ${ }^{a}$ & Type & Duration $^{b}$ & Year & \\
\hline A-1, km 99-153, C-N Spain & Not available & $1-20$ years & Monitoring & Short term & 2012 & 1 \\
\hline A-3, A-6 and M-40, C Spain & $1994-1997$ & $0-25$ years & Monitoring & 25 years & 1994-2019 & 2 \\
\hline A-3, km 59-74, C Spain & Not available & Unknown & Monitoring & Short term & Not available & 3 \\
\hline \multirow{2}{*}{ A-3, km 267-307, E Spain } & 1994 & 6 years & Monitoring & Short term & 2000 & 4 \\
\hline & 1994 & 8 years & Experiment & $1-1,5$ year & $2002-2004$ & 5 \\
\hline A-7, km 133-155, S Spain & 2001 & $1-3$ years & Monitoring & 2 years & $2002-2004$ & 6 \\
\hline C-32, km 103-130, NE Spain & 1993 & 1 year & Monitoring & 1 year & 1993-1994 & 7 \\
\hline \multirow{2}{*}{ M-12 and M-13, C Spain } & 2004 & $1-4$ years & Experiment & 3 years & $2005-2008$ & 8 \\
\hline & 2004 & 1 year & Experiment & 1 year & 2005 & 9 \\
\hline M-224, C Spain & 2009 & $1-2$ years & Experiment & 2 years & $2010-2011$ & 10 \\
\hline N-330, E Spain & 2003 & $0-2$ years & Monitoring & 2 years & $2004-2005$ & 11 \\
\hline R-4 and AP-36, C Spain & 2006 & $1-2$ years & Experiment & 2 years & $2007-2008$ & 12 \\
\hline Roads in C Spain (Madrid) & Not available & Unknown & Monitoring & Short term & 2009 & 13 \\
\hline Roads in N Spain (Navarra) & 1990-2000 & $2-15$ years & Monitoring & Short term & 2002 & 14 \\
\hline Roads in W Spain (Salamanca) & $1985-1995$ & $1-10$ years & Monitoring & Short term & Not available & 15 \\
\hline
\end{tabular}

Note: ${ }^{\mathrm{a}}$ Time between revegetation and study; ${ }^{\mathrm{b}}$ Time between first and last sampling; ${ }^{\mathrm{c}}$ References: ${ }^{1}$ Arenas et al. (2017a); ${ }^{2} \mathrm{Béjar}$ et al. (1994), Enríquez-de-Salamanca et al. (2002, 2004) and this paper; ${ }^{3}$ Arenas et al. (2017b); ${ }^{4}$ Bochet and García-Fayos (2004); ${ }^{5}$ Tormo et al. (2006), Bochet et al. (2007a); ${ }^{6}$ Matesanz et al. (2006); ${ }^{7}$ Andrés and Jorba (2000); ${ }^{8}$ De la Riva et al. (2011), Jiménez et al. (2013); ${ }^{9}$ Mola et al. (2011); ${ }^{10}$ Magro et al. (2014); ${ }^{11}$ Tormo et al. (2007, 2008); ${ }^{12}$ García-Palacios et al. (2010); ${ }^{13}$ Arenas et al. (2015); ${ }^{14}$ Etxeberría and Ibáñez (2005); ${ }^{15}$ Martín-Sanz et al. (2015) - these slopes were not revegetated. 
floristic diversity has changed, all related to the surrounding vegetation, which serves as a reference.

\section{Methods}

\subsection{Spatial and temporary scope}

The study covers three motorway sections located in Madrid, Central Spain (Figure 1). M40 $(3.9 \mathrm{~km})$ and A6 $(15.1 \mathrm{~km})$ motorways are West of Madrid while A3 $(22.4 \mathrm{~km})$ is East. Road sections have been chosen because we have participated in the drafting of the revegetation projects, in the execution of the road revegetation works and in the environmental monitoring. Revegetation projects were drafted in 1993 (A3) and 1994 (A6, M40), and revegetation works were executed in 1994 (A3), 1995 (A6) and 1997 (M40).

The study area is homogeneous in terms of climate and topography, varying the geological substrate. The climate is continental Mediterranean, with cold winters and hot summers; average temperature ranges between 14.0 and $14.3^{\circ} \mathrm{C}$ and annual rainfall 450 to $490 \mathrm{~mm}$, with summer minimum (dry period with water deficit). Altitude ranges between $500-700 \mathrm{~m}$.

A3 crosses Quaternary terrains in river valleys and a calcareous plateau; in the hillsides between the plateau and the valleys emerge gypsum and marls. M40 and A6 cross siliceous terrains, dominated by arkoses, coarsegrained sandstones rich in feldspar, originated by the degradation of granites. Around A6 and M40 the landscape includes silicicolous forests of Quercus rotundifolia Lam. with Juniperus oxycedrus L, scrublands dominated by Cistus ladanifer L. and Retama sphaerocarpa (L.) Boiss., reforestations of Pinus pinea L., and grasslands of ephemeral therophytes; and in A3 calcicolous forests of Quercus rotundifolia, Q. coccifera L. scrubs, reforestations of Pinus halepensis Mill., low bushes dominated by Thymus vulgaris L., Lavandula latifolia Medik. and Salvia officinalis L. subsp. lavandulifolia (Vahl) Gams on limestone and Gypsophila struthium Loefl. on gypsum, and cereal crops, olives and vineyards. A6 and M40 crosses highly urbanised areas, although bordering a large forest, while $\mathrm{A} 3$ borders an urban area in the beginning and then an agricultural area, although sparsely populated. Traffic intensity in 2019 (vehicles per day) is 150,000 on A-6, 136,000 on M-40, and 56,000 on A-3 (Ministerio de Transportes, Movilidad y Agenda Urbana [MITMA], 2019).

\subsection{Slope selection and characterisation}

We have analysed the dynamics of vegetation in a sample of road slopes of different types and geological substrates. Slopes are mainly soil roadcuts and embankments (fill slopes created by depositing material), but there are some rocky slopes in A3. A landslide in this motorway forced to reduce the angle of two roadcuts, placing gabion walls and a soil backfilling. Slope angle is $26-33^{\circ}$ in embankments, $30-50^{\circ}$ in soil roadcuts and up to $70^{\circ}$ in rock cuts. Revegetation treatments were topsoiling followed by hydroseeding with herbaceous species (woody species also in rock cuts) and planting (except rock slopes, both cuts and embankments).

The studied sample includes 50 slopes: 21 embankments (19 soil, 2 rock), 1 soil filling (false tunnel), 26 roadcuts ( 22 soil, 4 rock) and 2 roadcuts with gabion walls. For each slope we registered the type (roadcut or embankment), rockiness, revegetation treatments and maintenance (some slopes are mowed to reduce fire risk). Surrounding vegetation has influence on the seed rain received by the slopes (Bochet et al., 2007b; Mola et al., 2011), so we differentiated those adjacent to natural, agricultural or urban areas. According to these variables we

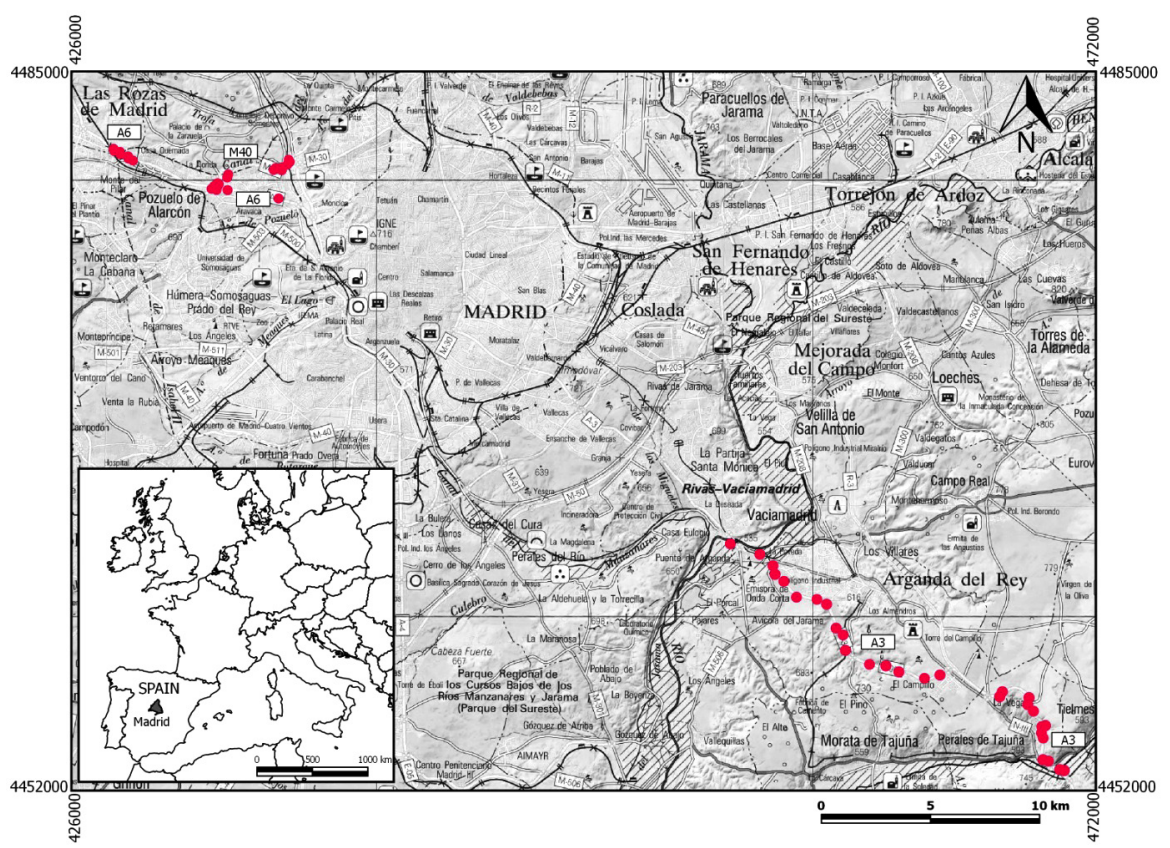

Figure 1. Location of the studied road slopes (UTM coordinates, ETRS89) 
defined 10 slope types (Table 2); each of the slopes studied falls into one of these types, all of which are represented, to a greater or lesser extent. We analysed vegetation cover in all the slopes, and plant composition in a smaller subsample of 15 slopes, selected throughout all the study areas on the condition that the slopes were representative of the ten defined types (Table 2), avoiding very small or unrepresentative slopes due to their morphology, and proportional to the number of slopes of each type. In addition, we have included 5 samples of surrounding vegetation bordering the slopes, usually natural vegetation, but sometimes disturbed by human actions, which serve as a reference to compare with the slopes. The size of the sampling plots has generally been $100 \mathrm{~m}^{2}$. Photographs of the slopes at different dates can be found in Supplementary Material 1 (SM1).

Table 2. Road slope types

\begin{tabular}{|c|c|c|c|c|c|}
\hline Type & $\begin{array}{l}\text { Slope } \\
\text { type }\end{array}$ & \multicolumn{2}{|c|}{$\begin{array}{l}\text { Geological } \\
\text { substrate }\end{array}$} & $\begin{array}{c}\text { Surrounding } \\
\text { area }\end{array}$ & $\begin{array}{l}\text { Main- } \\
\text { tenance }\end{array}$ \\
\hline T01 & \multirow{4}{*}{$\begin{array}{l}\text { Em- } \\
\text { bank- } \\
\text { ment or } \\
\text { filling }\end{array}$} & \multirow{3}{*}{$\begin{array}{l}\text { Calca- } \\
\text { reous }\end{array}$} & \multirow{2}{*}{ Soil } & Natural & - \\
\hline T02 & & & & Agricultural & - \\
\hline T03 & & & Rock & Natural & - \\
\hline T04 & & \multicolumn{2}{|c|}{$\begin{array}{l}\text { Siliceous } \\
\text { (arkoses) }\end{array}$} & Natural & - \\
\hline T05 & \multirow{6}{*}{ Roadcut } & \multirow{2}{*}{$\begin{array}{l}\text { Calca- } \\
\text { reous }\end{array}$} & Soil & Natural & - \\
\hline T06 & & & Rock & Natural & - \\
\hline T07 & & \multicolumn{2}{|c|}{ Gypsum } & Natural & - \\
\hline T08 & & \multirow{3}{*}{\multicolumn{2}{|c|}{$\begin{array}{l}\text { Siliceous } \\
\text { (arkoses) } \\
\text { Natural } \\
\text { Urban }\end{array}$}} & Natural & Mowing \\
\hline T09 & & & & - & \\
\hline T10 & & & & Mowing & \\
\hline
\end{tabular}

\subsection{Data collection and analysis}

Firstly, we reviewed revegetation projects, to understand what techniques were proposed, the used species and planting densities and actual on-ground works undertaken. Subsequently, we carried out two field work campaigns, in 2002 (5-8 years after construction) and 2019 (22-25 years after construction), to analyse plant cover and diversity of the slopes.

Plant cover was defined through a visual review of the whole slopes surface, and on the surrounding vegetation (as an average of 10 samples of $100 \mathrm{~m}^{2}$ ), with the support of orthophotos. We determined independent values for herbaceous and woody cover, using a scale from 1 (very low) to 5 (very high), related to plant cover percentages $(0-20 \%$ to $80-100 \%$ respectively). To define plant composition we used the relevé method (Supplementary Material 2 - SM2) to document plant composition in surrounding vegetation (5 samples) and revegetated slopes ( 15 slopes, sampled two times, in 2002 and 2019). Plant nomenclature followed the International Plant Names Index (IPNI, 2021), plant abundance was established according to the Braun-Blanquet (1932) method, and life-forms were defined according to Raunkiaer (1934). For each species we have indicated if they were introduced (by seeding or planting) or spontaneous colonisers, and their invasive character, considering their naturalisation and capacity of expansion in the slopes and the surrounding vegetation.

Using the relevés we made a hierarchical clustering that is a method of cluster analysis of observations (relevés in this study), to build a hierarchy among them, based on a measure of dissimilarity between them (in this case the index of Bray \& Curtis, 1957). The results were categorised according to slope types, obtaining partial results about plant cover, plant diversity, life forms, plant origin and persistence of species introduced in the revegetation. The effect of time, surrounding vegetation, and type of road slopes on the herbaceous and woody cover, plant diversity and life forms were analyzed using the t-Student test, performed with the software IBM SPSS 27.

\section{Results}

\subsection{Plant cover}

Herbaceous cover on slopes (3.1 over 5) was, on average, slightly lower than on surrounding vegetation (3.2/5) but the results were not significantly different (Table 3 ). Woody cover on slopes was $18 \%$ lower than in surrounding vegetation in 2002, statistically significant, but the difference was reduced to $3 \%$ lower in 2019 (Table 3), without significant difference. Herbaceous cover grew between 2002 and 2019 by $3 \%$, a statistically non-significant change, while woody cover grew by $17 \%$, a significant result.

In embankments (T01-T04), herbaceous and woody cover were not significantly different with respect to the surrounding vegetation (slightly lower in 2002 and slightly higher in 2019), and neither had it changed significantly between 2002 and 2019 (SM1, Figure SM12). The change in woody cover between 2002 and 2019 was not significant $(\mathrm{p}=0.06)$ due to the rock embankments (T03), which presented anomalous results due to their particularly difficult conditions for colonisation, but excluding this type of slopes the change was significant, with an increase in cover of $37 \pm 4 \%$; the woody cover on embankments has increased due to the growth and expansion of plants introduced in the revegetation. Herbaceous cover in roadcuts (T05-T10) did not show significant differences with respect to the surrounding vegetation. Differences in woody cover were not significant in 2002, but in 2019 they did not become significant $(\mathrm{p}=0.09)$ due to rock cuts $(\mathrm{T} 06)$, which, due to their physical limitations (rockiness), had limited vegetation development, but excluding this type of slopes, the result was significant; in both cases woody cover of the slopes was lower than that of the surrounding vegetation. Changes in woody cover between 2002 and 2019 were not significant because it was highly segmented: on limestone and gypsum cuts it grew by $25 \pm 4 \%$, with a significant result, while on arkose cuts the cover did not vary or decreased. 
Table 3. Plant cover of surrounding vegetation and changes over time in slope types

\begin{tabular}{|c|c|c|c|c|c|c|c|c|c|c|c|c|c|}
\hline \multirow{2}{*}{\multicolumn{2}{|c|}{$\begin{array}{l}\text { Type } \\
\text { SV }\end{array}$}} & \multicolumn{6}{|c|}{ Herbaceous cover } & \multicolumn{6}{|c|}{ Woody cover } \\
\hline & & \multicolumn{2}{|c|}{ Slopes in 2002} & \multicolumn{2}{|c|}{ Slopes in 2019} & \multirow{2}{*}{$\begin{array}{l}02 / 19 \\
-14 \%\end{array}$} & \multirow{2}{*}{$\frac{\text { SV }}{12 \%}$} & \multicolumn{2}{|c|}{ Slopes in 2002} & \multicolumn{2}{|c|}{ Slopes in 2019} & \multirow{2}{*}{$\begin{array}{c}02 / 19 \\
38 \%\end{array}$} & \multirow[b]{2}{*}{$45 \%$} \\
\hline \multirow{5}{*}{$\begin{array}{l}\text { Embank- } \\
\text { ment }\end{array}$} & T01 & 4.3 & 3.3 & $-23 \%$ & 3.7 & & & 2.1 & 2.0 & $-5 \%$ & 2.9 & & \\
\hline & T02 & 4.7 & 4.8 & $2 \%$ & 4.8 & $2 \%$ & $0 \%$ & 1.7 & 2.3 & $35 \%$ & 3.0 & $76 \%$ & $30 \%$ \\
\hline & T03 & 1.0 & 1.0 & $0 \%$ & 1.0 & $0 \%$ & $0 \%$ & 1.0 & 1.0 & $0 \%$ & 1.0 & $0 \%$ & $0 \%$ \\
\hline & T04 & 3.7 & 4.3 & $16 \%$ & 4.4 & $19 \%$ & $2 \%$ & 3.0 & 1.7 & $-43 \%$ & 2.3 & $-23 \%$ & $35 \%$ \\
\hline & $\mathrm{M} \pm \mathrm{SE}$ & $3.4 \pm 0.8$ & $3.4 \pm 0.8$ & $-1 \pm 8 \%$ & $3.5 \pm 0.9$ & $2 \pm 7 \%$ & $4 \pm 2 \%$ & $2.0 \pm 0.4$ & $1.8 \pm 0.3$ & $-3 \pm 16 \%$ & $2.3 \pm 0.5$ & $23 \pm 22 \%$ & $28 \pm 10 \%$ \\
\hline \multirow{7}{*}{ Roadcut } & T05 & 2.8 & 2.3 & $-18 \%$ & 2.7 & $-4 \%$ & $17 \%$ & 3.8 & 2.8 & $-26 \%$ & 3.2 & $-16 \%$ & $14 \%$ \\
\hline & T06 & 2.0 & 1.3 & $-35 \%$ & 1.5 & $-25 \%$ & $15 \%$ & 2.0 & 2.0 & $0 \%$ & 2.5 & $25 \%$ & $25 \%$ \\
\hline & T07 & 2.0 & 2.3 & $15 \%$ & 2.0 & $0 \%$ & $-13 \%$ & 3.0 & 2.0 & $-33 \%$ & 2.7 & $-10 \%$ & $35 \%$ \\
\hline & T08 & 4.0 & 4.0 & $0 \%$ & 5.0 & $25 \%$ & $25 \%$ & 3.0 & 1.0 & $-67 \%$ & 1.0 & $-67 \%$ & $0 \%$ \\
\hline & T09 & 3.5 & 4.0 & $14 \%$ & 2.8 & $-20 \%$ & $-30 \%$ & 3.3 & 2.3 & $-30 \%$ & 2.3 & $-30 \%$ & $0 \%$ \\
\hline & T10 & 3.9 & 3.8 & $-3 \%$ & 3.9 & $0 \%$ & $3 \%$ & 3.1 & 2.8 & $-10 \%$ & 2.4 & $-23 \%$ & $-14 \%$ \\
\hline & $\mathrm{M} \pm \mathrm{SE}$ & $3.0 \pm 0.4$ & $3.0 \pm 0.5$ & $-4 \pm 8 \%$ & $3.0 \pm 0.5$ & $-4 \pm 7 \%$ & $3 \pm 9 \%$ & $3.0 \pm 0.2$ & $2.2 \pm 0.3$ & $-28 \pm 9 \%^{*}$ & $2.4 \pm 0.3$ & $-20 \pm 12 \%$ & $10 \pm 7 \%$ \\
\hline Total & $\mathrm{M} \pm \mathrm{SE}$ & $3.2 \pm 0.4$ & $3.1 \pm 0.4$ & $-3 \pm 5 \%$ & $3.2 \pm 0.4$ & $-2 \pm 5 \%$ & $3 \pm 5 \%$ & $2.6 \pm 0.3$ & $2.0 \pm 0.3$ & $-18 \pm 9 \%^{*}$ & $2.3 \pm 0.2$ & $-3 \pm 13 \%$ & $17 \pm 6 \%^{*}$ \\
\hline
\end{tabular}

Note: Type: slope types (Table 2). SV: surrounding vegetation. Slopes: plant cover in 2002 and 2019 and difference with surrounding vegetation. 02/19: Changes between 2002 and 2019. Cover codes: 1(very low) to 5 (very high); the results are the mean of the values of all samples for each type of slope. $\mathrm{M} \pm \mathrm{SE}$ : Mean \pm standard error. t-test: difference respect surrounding vegetation; ${ }^{*}$ significant results (significance threshold of 0.05 ).

\subsection{Plant richness}

The slopes had on average $37 \%$ of the number of species of surrounding vegetation in 2002 (28 \pm 3 species) and $54 \%$ in 2019 ( $42 \pm 3$ species); the difference between years is a statistically significant result (Table 4 ), so there has been a progressive increase in the number of species of $53 \pm 9 \%$. Species richness and its increase are higher in embankments than in roadcuts.
Slopes with the highest proportion of species present in surrounding vegetation were gypsum roadcuts (T07), while the lowest occurred in arkose roadcuts that have been mowed (T08). The slopes had on average $65 \%$ more species than those used in revegetation in 2002 , and $147 \%$ more in 2019 , both statistically significant results.

Table 4. Number of species in surrounding vegetation, revegetation and slope types

\begin{tabular}{|c|c|c|c|c|c|c|c|c|c|c|c|c|c|c|c|}
\hline \multirow{2}{*}{\multicolumn{2}{|c|}{ Type }} & \multirow{3}{*}{$\begin{array}{c}\mathrm{N}_{\mathrm{S}} \\
102\end{array}$} & $\mathrm{~N}_{\mathrm{R}}$ & \multicolumn{4}{|c|}{ Slopes 2002} & \multicolumn{4}{|c|}{ Slopes 2019} & \multicolumn{4}{|c|}{ Change 2002-2019 } \\
\hline & & & \multicolumn{2}{|c|}{$\mathrm{N}_{\mathrm{S}}$} & \multicolumn{2}{|c|}{$\mathrm{P}_{\mathrm{R}}$} & \multicolumn{2}{|c|}{$\mathrm{N}_{\mathrm{S}}$} & \multicolumn{2}{|c|}{$\mathrm{P}_{\mathrm{R}}$} & \multicolumn{2}{|c|}{$\mathrm{N}_{\mathrm{S}}$} & \multicolumn{2}{|c|}{$\mathrm{P}_{\mathrm{R}}$} & \multirow[b]{2}{*}{$0 \%$} \\
\hline \multirow{5}{*}{ 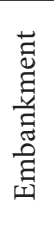 } & T01 & & 22 & 29 & $28 \%$ & 12 & $55 \%$ & 50 & $49 \%$ & 12 & $55 \%$ & 21 & $72 \%$ & 0 & \\
\hline & T02 & 82 & 26 & 42 & $51 \%$ & 16 & $62 \%$ & 52 & $63 \%$ & 13 & $50 \%$ & 10 & $24 \%$ & -3 & $-19 \%$ \\
\hline & T03 & 53 & 8 & 17 & $32 \%$ & 1 & $13 \%$ & 28 & $53 \%$ & 1 & $13 \%$ & 11 & $65 \%$ & 0 & $0 \%$ \\
\hline & T04 & 99 & 20 & 34 & $34 \%$ & 13 & $65 \%$ & 60 & $61 \%$ & 9 & $45 \%$ & 26 & $76 \%$ & -4 & $-31 \%$ \\
\hline & $\mathrm{M} \pm \mathrm{SE}$ & $84 \pm 11$ & $19 \pm 4$ & $31 \pm 5$ & $36 \pm 5 \%^{*}$ & $11 \pm 3$ & $48 \pm 12 \%^{*}$ & $48 \pm 7$ & $57 \pm 3 \%^{*}$ & $9 \pm 3$ & $41 \pm 10 \%{ }^{*}$ & $17 \pm 4$ & $59 \pm 12 \%^{*}$ & $-2 \pm 1$ & $-12 \pm 8 \%$ \\
\hline \multirow{7}{*}{ 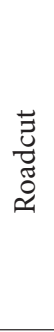 } & T05 & 102 & 22 & 40 & $39 \%$ & 14 & $64 \%$ & 58 & $57 \%$ & 14 & $64 \%$ & 18 & $45 \%$ & 0 & $0 \%$ \\
\hline & T06 & 53 & 8 & 21 & $40 \%$ & 4 & $50 \%$ & 32 & $60 \%$ & 3 & $38 \%$ & 11 & $52 \%$ & -1 & $-25 \%$ \\
\hline & T07 & 44 & 12 & 30 & $68 \%$ & 6 & $50 \%$ & 33 & $75 \%$ & 4 & $33 \%$ & 3 & $10 \%$ & -2 & $-33 \%$ \\
\hline & T08 & 99 & 18 & 16 & $16 \%$ & 6 & $33 \%$ & 32 & $32 \%$ & 5 & $28 \%$ & 16 & $100 \%$ & -1 & $-17 \%$ \\
\hline & T09 & 99 & 20 & 24 & $24 \%$ & 15 & $75 \%$ & 41 & $41 \%$ & 15 & $75 \%$ & 17 & $71 \%$ & 0 & $0 \%$ \\
\hline & T10 & 75 & 10 & 31 & $41 \%$ & 6 & $60 \%$ & 36 & $48 \%$ & 4 & $40 \%$ & 5 & $16 \%$ & -2 & $-33 \%$ \\
\hline & $\mathrm{M} \pm \mathrm{SE}$ & $79 \pm 10$ & $15 \pm 2$ & $27 \pm 3$ & $38 \pm 7 \%^{*}$ & $9 \pm 2$ & $55 \pm 6 \%{ }^{*}$ & $39 \pm 4$ & $52 \pm 6 \%{ }^{*}$ & $8 \pm 2$ & $46 \pm 8 \%{ }^{*}$ & $12 \pm 3$ & $49 \pm 14 \%^{*}$ & $-1 \pm 0$ & $-18 \pm 6 \%{ }^{*}$ \\
\hline 胥 & $\mathrm{M} \pm \mathrm{SE}$ & $81 \pm 7$ & $17 \pm 2$ & $28 \pm 3$ & $37 \pm 5 \%^{*}$ & $9 \pm 2$ & $53 \pm 6 \%$ * & $42 \pm 4$ & $54 \pm 4 \%^{*}$ & $8 \pm 2$ & $44 \pm 6 \%^{*}$ & $14 \pm 2$ & $53+9 \% *$ & $-1 \pm 0$ & $-16 \pm 5 \%{ }^{*}$ \\
\hline
\end{tabular}

Note: Type: Slope types (Table 2). $\mathrm{N}_{\mathrm{S}}$ : Number of species in surrounding vegetation. $\mathrm{N}_{\mathrm{R}}$ : Number of species used in revegetation (planting/seeding). $\mathrm{N}_{S}$ : Number of species in slopes. $\mathrm{P}_{\mathrm{R}}$ : Persistence of species used in revegetation. $\mathrm{M} \pm \mathrm{SE}$ : Mean \pm standard error. $\mathrm{t}$-test: difference between means; ${ }^{*}$ significant (significance threshold of 0.05). 


\subsection{Life-forms}

Life-forms varied widely in surrounding vegetation (Table 5): therophytes dominated in agricultural and urban areas $(83-88 \%)$, while chamaephytes were dominant on gypsum (49\%) and rocky limestone areas (40\%). This composition influenced slope colonisation (Table 5). Slopes in arkoses (T04, T08-T10) had a higher proportion of therophytes, a mean on $69 \%$, than those in limestone and gypsum (T01-T03, T05-T07), with a mean of $33 \%$; t-test shows that the difference is highly significant $(\mathrm{p}=0.0005)$. There was a high presence of chamaephytes (35\%) in gypsum and limestone roadcuts (T05-T07), like surrounding vegetation (40\%), while in arkoses (T04, T08-T10) and cultivated areas (T02) their presence was scarce (1\%); the difference is also statistically very significant. Percentages of nano and macrophanerophytes on the slopes ( $10 \pm 2 \%$ and $8 \pm 1 \%$ respectively) were higher than in the surrounding vegetation $(8 \pm 1 \%$ and $5 \pm 1 \%)$; the results of the relevés showed that the species of nanophanerophytes that appeared on the slopes were those introduced in revegetation, while macrophanerophytes species were mainly invasive species, not used in revegetation.

\subsection{Invasive species}

Native plants dominated the surrounding vegetation (95-98\%) and the slopes (87-96\%); alien plants occurrence was higher on slopes, with some species absent in surrounding vegetation. Slopes with more invasive species were embankments in agricultural areas (T02, 6.5 species) and in arkoses (T04, 6 species); t-test shows a significant difference $(p=0.0007)$.

\subsection{Persistence of revegetated species}

Persistence of species used in revegetation was on average $56 \%$ in 2002 and $48 \%$ in 2019 (Table 4), a difference which, according to the t-test performed, is statistically significant. The highest persistence values in 2019 were obtained in roadcuts in arkoses (75\%, T08-10) and calcareous soils $(64 \%, \mathrm{~T} 05)$. Although plant persistence in number of species was important, dominance was variable: dominance of herbaceous plants introduced was low, with just a few scattered specimens (only one embankment, included in T04 type, has local dominance of Thinopyrum intermedium (Host) Barkworth \& D.R. Dewey; Figure S12-SM1), while in woody plants was greater, especially in calcareous soil embankments (T01-T02).

\subsection{Hierarchical clustering}

The dendrogram obtained through hierarchical clustering showed a clear difference between vegetation in siliceous soils and in gypsum and limestone. The similarity among slopes, and of the slopes with the surrounding vegetation, is higher in siliceous areas, probably due to the lower plant diversity of these areas; only relevé 6a stood out (see Figures S11-SM1 and SM2), a soil roadcut with severe colonisation problems (Figure 2). In the calcareous-gypsum area the differences among slopes were greater. In this area, the greater similarity with surrounding vegetation was found in gypsum slopes. Among the slopes in calcareous areas, the differences between those located in agricultural and natural environments were clear. It was noteworthy the similarity of relevé $20 \mathrm{~b}$ (a roadcut with gabion walls; see Figure S5-SM1 and SM1) with the surrounding vegetation. The similarity of slope vegetation to the surrounding

Table 5. Percentage of life-forms in surrounding vegetation and slope types

\begin{tabular}{|c|c|c|c|c|c|c|c|c|c|c|c|c|c|c|c|c|}
\hline \multirow{2}{*}{\multicolumn{2}{|c|}{$\begin{array}{l}\text { Type } \\
\text { SV }\end{array}$}} & \multicolumn{3}{|c|}{$\mathrm{T}$} & \multicolumn{3}{|c|}{$\mathrm{H}$} & \multicolumn{3}{|c|}{ C } & \multicolumn{3}{|c|}{ NP } & \multicolumn{3}{|c|}{ MP } \\
\hline & & 2002 & 2019 & SV & 2002 & 2019 & SV & 2002 & 2019 & SV & 2002 & 2019 & SV & 2002 & 2019 & \\
\hline \multirow{5}{*}{ Emb. } & T01 & 34 & 34 & 36 & 17 & 14 & 16 & 31 & 14 & 20 & 13 & 28 & 18 & 5 & 10 & 10 \\
\hline & T02 & 83 & 55 & 58 & 10 & 12 & 15 & 2 & 10 & 6 & 5 & 17 & 13 & 0 & 7 & 8 \\
\hline & T03 & 32 & 53 & 29 & 17 & 6 & 21 & 40 & 41 & 29 & 9 & 0 & 14 & 2 & 0 & 7 \\
\hline & T04 & 61 & 56 & 64 & 13 & 18 & 17 & 8 & 6 & 0 & 7 & 9 & 7 & 10 & 12 & 12 \\
\hline & $\mathrm{M} \pm \mathrm{SE}$ & $53 \pm 12$ & $50 \pm 5$ & $47 \pm 9$ & $14 \pm 2$ & $12 \pm 2$ & $17 \pm 1$ & $20 \pm 9$ & $18 \pm 8$ & $14 \pm 7$ & $9 \pm 2$ & $13 \pm 6$ & $13 \pm 2$ & $4 \pm 2$ & $7 \pm 3$ & $9 \pm 1$ \\
\hline \multirow{7}{*}{ Cut } & T05 & 34 & 33 & 26 & 17 & 18 & 26 & 31 & 30 & 29 & 13 & 15 & 14 & 5 & 5 & 5 \\
\hline & T06 & 32 & 29 & 28 & 17 & 24 & 16 & 40 & 29 & 38 & 9 & 14 & 13 & 2 & 5 & 6 \\
\hline & T07 & 28 & 30 & 24 & 14 & 20 & 15 & 49 & 47 & 52 & 7 & 3 & 3 & 2 & 0 & 6 \\
\hline & T08 & 61 & 69 & 69 & 13 & 19 & 16 & 8 & 0 & 0 & 7 & 0 & 6 & 10 & 13 & 9 \\
\hline & T09 & 61 & 46 & 61 & 13 & 13 & 12 & 8 & 17 & 5 & 7 & 17 & 12 & 10 & 8 & 10 \\
\hline & T10 & 88 & 84 & 81 & 8 & 13 & 8 & 1 & 0 & 3 & 0 & 3 & 3 & 3 & 0 & 6 \\
\hline & $\mathrm{M} \pm \mathrm{SE}$ & $51 \pm 10$ & $48 \pm 9$ & $48 \pm 10$ & $13 \pm 1$ & $18 \pm 2$ & $15 \pm 2$ & $23 \pm 8$ & $20 \pm 8$ & $21 \pm 9$ & $7 \pm 2$ & $9 \pm 3$ & $8 \pm 2$ & $5 \pm 2$ & $5 \pm 2$ & $7 \pm 1$ \\
\hline Total & $\mathrm{M} \pm \mathrm{SE}$ & $52 \pm 7$ & $49 \pm 6$ & $48 \pm 7$ & $14 \pm 1$ & $15 \pm 2$ & $16 \pm 1$ & $22 \pm 6$ & $19 \pm 5$ & $18 \pm 6$ & $8 \pm 1$ & $11 \pm 3$ & $10 \pm 2$ & $5 \pm 1$ & $6 \pm 2$ & $8 \pm 1$ \\
\hline
\end{tabular}

Note: Type: slope types (Table 2). SV: surrounding vegetation. T: Therophytes. H: Hemicryptophytes. C: Chamaephytes. N: Nanophanerophytes. MP: Macrophanerophytes. All values in percentages. $\mathrm{M} \pm \mathrm{SE}$ : Mean \pm standard error. 


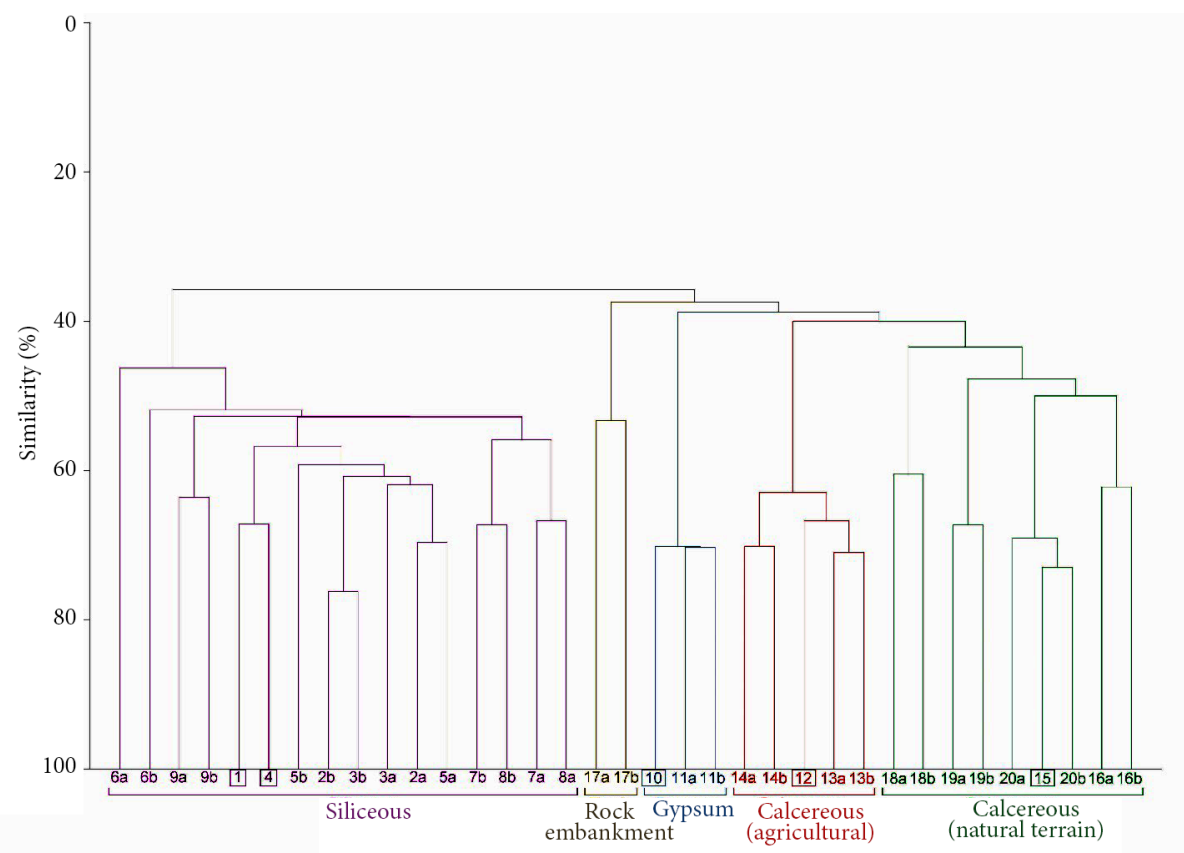

Figure 2. Dendrogram of vegetation relevés. Boxes: surrounding vegetation; a: relevés in 2002; b: relevés in 2019

vegetation, as evidenced by the hierarchical clustering, illustrates the influence of surrounding vegetation on the dynamics of slope vegetation.

\section{Discussion}

\subsection{Influence of slope characteristics}

Bochet et al. (2009) calculated angles thresholds for plant colonisation, which varied with orientation (from $63^{\circ} \mathrm{N}$ to $41^{\circ} \mathrm{S}$ ); these authors previously stated that there was virtually no vegetation on slopes greater than $45^{\circ}$ (Bochet \& García-Fayos, 2004). Our results showed that inclination itself was insufficient to determine the presence of vegetation, with other aspects such as geology or applied treatment having great influence.

Slope geology is scarcely addressed in the analysed studies, but in our study it had influence on plant colonisation. We have detected greater difficulty for plant colonisation in some arkose roadcuts (T09); although plant diversity increased over time, herbaceous plant cover was reduced between 2002 and 2019 (Table 3; Figure S10 and S11-SM1). Similarly, surrounding vegetation in arkoses has a poor cover of ephemeral therophytes, with high percentage of bare soil. Martín-Sanz et al. (2015) indicated also that natural colonisation is less active on granites (arkoses come from granite degradation).

Calcareous and gypsum terrains are rich in chamaephytes, which greatly favours roadcuts' colonisation, because this life-form is highly adapted to rocky and dry areas, replacing hemicryptophytes in large extent in Mediterranean habitats; in embankments its presence was lower, especially in agricultural surroundings.

Gypsum seems a priori a hostile terrain. Etxeberría and Ibáñez (2005) analysed revegetation of marl slopes in Navarra (N Spain), concluding that after hydroseeding a vegetation cover is implanted, but undergoes an arrested succession (Alday et al., 2014), and no plant was able to colonise the slopes remarkably. Matesanz and Valladares (2007) carried out greenhouse experiments using soils from gypsum slopes, concluding that fast-growing commercial species (especially Lolium rigidum Gaudin) impede the development of gypsophilous species. Both were short-term studies; although these observations may be true in the first years, our results did not confirm them in the long term. The initial plant development on the analysed gypsum roadcuts was poor, but in the long term, it has been very positive. The persistence of species used in revegetation gradually decreased $(50 \%$ eight years after revegetation and 33\% 25 years after). The initial dominance of commercial species was not maintained over time; the slopes evolved, and gypsophilous species, highly adapted, colonised its surface, favoured by an herbaceous cover that reduced seed drag. Between 2002 and 2019, herbaceous cover, dominated by therophytes, was reduced, but in exchange for a growth of a woody cover of gypsophilous chamaephytes and to the development of a biological lichen crust (personal observation, SM2); as a result, these slopes have currently gypsophilous bushes like the natural areas (Figure S4-SM1).

Rockiness, the amount of outcropping rock and its degree of fragmentation, affects plant colonisation. In compact rock plant colonisation is limited, but often rocky slopes are fragmented; as noted by Martínez-Ruiz et al. (2001), the mere breaking-up of the original parent material accelerates the natural revegetation. Rock embankments (T03) and cuts (T06) had the lowest herbaceous cover in 2002 and 2019, and the former also the lowest woody cover. In rock cuts (T06) a specific seed mixture 
was used, including chamaephytes (Lavandula latifolia, Salvia officinalis subsp. lavandulifolia and Thymus vulgaris), with favourable results, reaching a $35 \%$ of woody cover (Figure S8-SM1). In gypsum roadcuts, despite the presence of crystalline gypsum, colonisation has also been favourable. Rock embankments were quite different from the rest because they were deposits of coarse rocks where vegetation could not develop, with a scarce supply of disaggregated soil on the slope head; as a consequence, the results obtained were very different from the rest of the slopes.

\subsection{Revegetation techniques}

Road slopes are poor in organic matter, so usually a layer of topsoil is spread, as in the cases of the slopes analysed in this study. Organic matter in topsoil is often scarce in the Mediterranean region, especially in agricultural areas; the analyses carried out during revegetation works showed values of $1-3 \%$. Topsoil did not contribute nutritionally to plant growth, but improves soil properties and water relations, favouring the survival and growth of sown species, and allowing a greater vegetation cover in a shorter time, although higher thickness does not improve plant cover or richness (Cotts et al., 1991; Jiménez et al., 2013; Mola et al., 2011; Magro et al., 2014; Rivera et al., 2014). Another advantage of topsoil is to store seeds of local plants, most of them not commercialised, reinforcing hydroseedings; the enrichment in species obtained in our results seems to be favoured by the use of topsoil in the slopes. Mola et al. (2011) indicated that the seed bank of the topsoil was very poor, and González-Alday et al. (2009) also detected few seeds in mine soils before hydroseeding; probably the location (grasslands, crops, woodlands) and the excavation date (before or after seed maturation) may have a significant influence in seed amount and composition.

Revegetation after topsoiling in the studied slope was done by sowing and planting, in a complementary way: the former created herbaceous covers and the latter woody covers. Hydroseeding has been developed in temperate climates, where it is successful technique, but in the Mediterranean, with a very different climate, it may fail (Martínez-Ruiz et al., 2007; Tormo et al., 2007; García-Palacios et al., 2010). Mola et al. (2011) stated that hydroseeding invariably failed, regardless of seed mixture and road slope type. However, our results (and those of other authors) do not support such a categorical statement: the analysed slopes, all of them hydroseeded, had in 2019 a mean herbaceous cover of $60 \%$ and 42 plant species, without erosion problems, so hydroseeding cannot be considered to have failed. Hydroseeding results highly depend on the annual climate (e.g. rain distribution or length of the dry season), the design (e.g. seed mixture) and the application form and date, so it is difficult to generalize.

Our results pointed to a regressive trend in the presence of plant species employed in revegetation, with lower persistence is sown than in planted species. However, the lack of persistence of hydroseeded species over time does not imply a failure in revegetation; the herbaceous cover implanted through hydroseeding was a transitory stage, whose main objective should be stop erosion in the short term, allowing plant colonisation on the slopes. The composition of seed mixtures is important for hydroseeding success (Tinsley et al., 2006; Martínez-Ruiz et al., 2007). The use of native species improves sowing results compared to commercial mixtures (Tormo et al., 2007; Bochet et al., 2010a; Hilvers et al., 2017); all the seed mixtures used in the studied slopes were specifically designed, and non commercial. When the species selected are adapted to climate and local constraints they can persist more time, contributing to preserving the vegetation cover, so species selection is a key factor to improve revegetation in the short- and medium-term. However, there was a lack of useful plant coloniser seeds in the market (e.g. Bromus tectorum L., B. rubens L., B. matritensis L., Avena sterilis L., A. barbata Pott ex Link or Hordeum murinum L.); probably their use would improve short-term results. Vegetal materials collected on site (mainly seeds) produced greater plant cover than those purchased from commercial suppliers (Cotts et al., 1991). Seed quality -mainly established though purity and germination capacity- is also important; Cynodon dactylon (L.) Pers. had poor results in the studied slopes, consistent with the low germination results obtained in our seed analysis conducted during revegetation works.

In Mediterranean climates herbaceous cover is rich in therophytes and woody cover in chamaephytes, while in temperate climates usually dominate hemicryptophytes and nanophanerophytes respectively. However, the proportion of hemicryptophytes in the seed mixture was high, which is often the case in revegetation projects in Spain. Our results showed a low initial success of hemicryptophytes after hydroseeding, and those that remain (e.g. Dactylis glomerata L.) usually grow in a scattered way. During succession we have detected a replacement of vital forms, from therophytes to hemicryptophytes, consistent with Martínez-Ruiz and Marrs (2007) and Martín-Sanz et al. (2015). Raevel et al. (2013) indicated for Mediterranean roadcuts in France that along the first 30 years the initially abundant short-lived species declined and were replaced by longer lived herbaceous and woody species. However, in early stages therophytes are necessary to stabilise the slopes and allow the beginning of the colonisation process. Consequently, it may be interesting to reduce the weight of hemicryptophytes in hydroseeding in Mediterranean climates, increasing the percentage of therophytes and including seeds of chamaephytes. Jaúregui et al. (2013) recommended a higher percentage of legumes to reduce litter accumulation on road slopes; however, our results showed a regressive trend of this group over time, so increasing their percentage in seed mixtures can lead to a lower plant cover.

Arenas et al. (2015) indicated that woody-planted vegetation did not have a facilitating effect on natural colonisation. In our results, persistence of woody plants 
was $48 \%$, and in embankments represented nearly all the woody cover, given rise to vegetation patches that have spread over the slopes (Figures S6 and S7-SM1). A key factor was the use of native species; in the studied slopes planted specimens and those that have colonised naturally are now indistinguishable. These authors considered natural succession sufficiently effective as a passive restoration on embankments in the long term; however, our results 25 years after revegetation showed that there is only a noticeable spontaneous woody cover on embankments where it was planted (excluding invasive trees). Some species have difficulties for natural colonisation of the slopes due to seed size or dispersion mechanism but have had good results in planting (e.g. Quercus rotundifolia and Q. coccifera).

\subsection{Plant cover}

Bochet and García-Fayos (2004) indicated that vegetation cover was $44-78 \%$ in embankments and did not reach $10 \%$ in roadcuts, while Matesanz et al. (2006) results were $80-90 \%$ in the former and $18-30 \%$ in the latter; both are short term results. Our long-term results (excluding rock slopes due to physical limitations) were $74-96 \%$ of herbaceous cover and $31-40 \%$ of woody cover in embankments, and $40-90 \%$ and $10-53 \%$ respectively in roadcuts. Herbaceous cover was greater in embankments, but the woody cover was variable. Plant cover on slopes, especially herbaceous cover, pointed to a successful revegetation, because results achieved were similar to that expected (plant cover in the surrounding vegetation).

Mola et al. (2011) obtained a continued cover growth during the first two years; our results showed a longterm increase of vegetation cover, not only in the short term. Herbaceous cover has grown since the execution of the revegetation, at an accelerated rate in the first years (higher than $2.5 \%$ per year) and much lower later $(0.2 \%$ per year). Woody cover decreased after revegetation as a result of plant mortality (around $-0.7 \%$ per year) but it increased over time (1.2\% per year) when the surviving plants grew and new specimens colonised. In precedent studies vegetation cover was analysed together; however, our results were quite different between herbaceous and woody cover. Planting in slopes had a major impact on woody cover, especially in embankments (roadcuts are more easily colonised by chamaephytes).

\subsection{Plant composition and diversity}

Seed rain from adjacent vegetation is an important factor in slope colonisation (Bochet et al., 2007b; De la Riva et al., 2011; Mola et al., 2011), greater than hydroseeding, and is determined by the distance to vegetation. MartínSanz et al. (2015) indicated that the plant communities on the slopes are rich in species when an adjacent seed source is present, although other aspects had also influence, such as geology or inclination. The hierarchical clustering of the relevés showed a big similarity between surrounding vegetation and nearby slopes. Slopes on calcareous terrains in A3 had similar revegetation treatment, but those close to natural terrains were clearly different to the ones near agricultural areas. Slopes in gypsum had also the same treatment but they are currently very different.

Our results showed increased species richness on slopes over time, consistent with De la Riva et al. (2011), due to spontaneous colonisation. On average, plant diversity of slopes has increased with respect to revegetation by $65 \%$ in 2002 and $147 \%$ in 2019 . Mola et al. (2011) cited a richness growth during the first two years, which our results confirmed much longer over time. Matesanz et al. (2006) indicated that plant diversity was higher in embankments (50-70 species) than in roadcuts (6-10 species); our results were 52-60 species in embankments and $33-58$ in roadcuts, but the richest slope was a roadcut with 84 species. Therefore, although diversity values were on average somewhat higher in embankments, they were close to that of roadcuts; Martín-Sanz et al. (2015) also found high diversity values in roadcuts. Colonisation processes are slower in roadcuts (Bochet et al., 2011), so that may justify the low diversity found by Matesanz et al. (2006), maybe for being analysed at an early stage of colonisation.

De la Riva et al. (2011) indicated that hydroseeded species persisted over time but did not modify community composition or dynamics. Our results only supported that partially; hydroseeded species reduced their abundance on slopes over time but were sometimes locally dominant (e.g. Thinopyrum intermedium in one embankment or Lavandula officinalis subsp. latifolia in rock cuts).

Arenas et al. (2017b) suggested that roadsides were excellent biodiversity reservoirs. In agricultural areas, road slopes may be a refuge for woody species, disappeared as a result of agrarian intensification. In our study embankments are a refuge for nanophanerophytes introduced in the revegetation, disappeared from the surrounding area (Figure S7-SM1)

\subsection{Alien species}

The presence of invasive species was greater on slopes than in the surrounding vegetation. Half of invasive plants were trees, the most common Ailanthus altissima (Mill.) Swingle and Ulmus pumila L., growing in all slope types and geological substrates (Figure S1-SM1). Arenas et al. (2017a) considered successful tree colonisation of slopes, but among the species they included was Ulmus pumila, an invasive plant in Spain. The main route of entry for invasive plants was the road itself, because usually they were not present in surrounding vegetation.

Arévalo et al. (2005) detected in the Canary Islands that higher disturbance on roadsides promoted alien plants, and Fowler et al. (2008) found significantly higher exotic species richness in roadsides than in adjacent forest habitats. Our results showed that the slopes with greater similarity to surrounding vegetation were roadcuts, which presented more difficulties for plant colonisation; easier 
conditions for colonisation, as in embankments, seemed to favour ruderal and invasive species.

\subsection{Slope maintenance and other limitations}

Fire risk in the Mediterranean is high, and roads are potential sources, so roadsides are often mowed (Figure S2SM1). Mowing had negative influence on woody cover, but the obtained dendrogram did not show clear differences in terms of plant composition; however, mowed slopes (T08, T10) had the lowest proportion of species from the surrounding vegetation, and the highest proportion of therophytes, both in urban $(81 \%, \mathrm{~T} 10)$ and natural areas $(69 \%$, T08).

We detected proliferations of rabbits in some embankments (T04), affecting plant cover; these slopes were easy to dig, and predators had not access due to road fences (that rabbits cross easily), so it was an optimal habitat (Figure S9-SM1).

\section{Conclusions}

The aim of this study was to analyse vegetation changes in road slopes over time, from revegetation until after 22-25 years, comparing them with the surrounding vegetation. On embankments herbaceous cover was similar to that of the surrounding vegetation in 2002, and even exceeded it by 2019 , while woody cover was initially lower than the surrounding vegetation but in 2019 it slightly exceeded it. In roadcuts the herbaceous cover remains stable over time, similar to that of the surrounding vegetation, while woody cover was lower, although growing between 2002 and 2019.

Plant diversity on the slopes increases over time: in the revegetation an average of 19 species were used in embankments and 17 in cuttings, but in 2002 the number reached 31 and 27 respectively, and in 201948 and 39. Consequently, there is a diversification of plant cover over time.

Plant colonisation was easier in embankments but it was also effective in roadcuts, even in rocky areas. Roadsides are prone to ruderal and invasive plant colonisation, but the more difficult the slope conditions are for plants, the greater their naturalness; roadcuts in gypsum presented the lowest amount of exotic species, while embankments had the highest value.

Two recommendations to improve revegetation are to produce seeds of spontaneous colonizing species and to include higher proportions of therophytes and chamaephytes in seed mixtures.

Plant colonisation and succession processes are not linear, so their study requires prolonged observations over time. This study is only one more stage, and not a final result. It is necessary a continuous monitoring of slope vegetation to achieve an increasingly precise knowledge of its dynamics, and thus improve revegetation processes.

\section{References}

Alday, J. G., Santana, V. M., Marrs, R. H., \& Martínez-Ruiz, C. (2014). Shrub-induced understory vegetation changes in reclaimed mine sites. Ecological Engineering, 73, 691-698. https://doi.org/10.1016/j.ecoleng.2014.09.079

Andrés, P., \& Jorba, M. (2000). Mitigation strategies in some motorway embankments (Catalonia, Spain). Restoration Ecology, 8(3), 268-275.

https://doi.org/10.1046/j.1526-100x.2000.80038.x

Arenas, J. M., Escudero, A., Magro, S., Balaguer, L., \& Casado, M. A. (2015). Woody colonization of road embankments: A large spatial scale survey in central Spain. Landscape and Urban Planning, 141, 52-58.

https://doi.org/10.1016/j.landurbplan.2015.04.009

Arenas, J. M., Escudero, A., Mola, I., \& Casado, M. A. (2017b). Roadsides: An opportunity for biodiversity conservation. Applied Vegetation Science, 20(4), 527-537. https://doi.org/10.1111/avsc. 12328

Arenas, J. M., Lázaro-Lobo, A., Mola, I., Escudero, A., \& Casado, M. A. (2017a). The influence of site factors and proximity of adjacent vegetation on tree regeneration into roadslopes. Ecological Engineering, 101, 120-129. https://doi.org/10.1016/j.ecoleng.2017.01.007

Arévalo, J. R., Delgado, J. D., Otto, R., Naranjo, A., Salas, M., \& Fernández-Palacios, J. M. (2005). Distribution of alien vs. native plant species in roadside communities along an altitudinal gradient in Tenerife and Gran Canaria (Canary Islands). Perspectives in Plant Ecology, Evolution and Systematics, 7(3), 185-202. https://doi.org/10.1016/j.ppees.2005.09.003

Aronson, J., Floret, C., LeFloc'h, E., Ovalle, C., \& Pontanier, R. (1993). Restoration and rehabilitation of degraded ecosystems in arid and semi-arid lands. I. A view from the south. Restoration Ecology, 1(1), 8-17. https://doi.org/10.1111/j.1526-100X.1993.tb00004.x

Bakker, J. P., Grootjans, A. P., Hermy, M., \& Poschlod, P. (2000). How to define targets for ecological restoration? - Introduction. Applied Vegetation Science, 3(1), 3-7. https://doi.org/10.1111/j.1654-109X.2000.tb00033.x

Béjar, M., Carrasco, M. J., \& Enríquez-de-Salamanca, Á. (1994). Restauración vegetal de los terrenos afectados por la Autovía de Levante (N-III). Tramo Arganda-Perales de Tajuña. Rutas, $42,35-42$.

Bochet, E., \& García-Fayos, P. (2004). Factors controlling vegetation establishment and water erosion on motorway slopes in Valencia, Spain. Restoration Ecology, 12(2), 166-174. https://doi.org/10.1111/j.1061-2971.2004.0325.x

Bochet, E., García-Fayos, P., \& Poesen, J. (2009). Topographic thresholds for plant colonization on semi-arid eroded slopes. Earth Surface Processes and Landforms, 34(13), 1758-1771. https://doi.org/10.1002/esp.1860

Bochet, E., García-Fayos, P., \& Tormo, J. (2007b). Road slope revegetation in semiarid Mediterranean environments. Part I: seed dispersal and spontaneous colonization. Restoration Ecology, 15(1), 88-96. https://doi.org/10.1111/j.1526-100X.2006.00193.x

Bochet, E., García-Fayos, P., \& Tormo, J. (2010b). How can we control erosion of roadslopes in semiarid Mediterranean areas? Soil improvement and native plant establishment. Land Degradation \& Development, 21(2), 110-121. https://doi.org/10.1002/ldr.911

Bochet, E., García-Fayos, P., Alborch, B., \& Tormo, J. (2007a). Soil water availability effects on seed germination account 
for species segregation in semiarid roadslopes. Plant and Soil, 295, 179-191. https://doi.org/10.1007/s11104-007-9274-9

Bochet, E., García-Palacios, P., Peco, B., Tormo, J., \& García-Fayos, P. (2011). Procesos ecológicos y restauración de la cubierta vegetal. In F. Valladares, L. Balaguer, I. Mola, A. Escudero, \& V. Alfaya (Eds.), Restauración ecológica de áreas afectadas por infraestructuras de transporte. Bases científicas para soluciones técnicas (pp. 101-141). Fundación Biodiversidad.

Bochet, E., Tormo, J., \& García-Fayos, P. (2010a). Native Species for roadslope revegetation: Selection, validation, and cost effectiveness. Restoration Ecology, 18(5), 656-663. https://doi.org/10.1111/j.1526-100X.2008.00496.x

Braun-Blanquet, J. (1932). Plant sociology: The study of plant communities. McGraw-Hill.

Bray, J. R., \& Curtis, J. T. (1957). An ordination of upland forest communities of southern Wisconsin. Ecological Monographs, 27(4), 325-349. https://doi.org/10.2307/1942268

Cotts, N. R., Redente, E. F., \& Schiller, R. (1991). Restoration methods for abandoned roads at lower elevations in GrandTeton National-Park, Wyoming. Arid Soil Research and Rehabilitation, 5(4), 235-249.

https://doi.org/10.1080/15324989109381284

De la Riva, E. G., Casado, M. A., Jiménez, M. D., Mola, I., CostaTenorio, M., \& Balaguer, L. (2011). Rates of local colonization and extinction reveal different plant community assembly mechanisms on road verges in central Spain. Journal of Vegetation Science, 22(2), 292-302.

https://doi.org/10.1111/j.1654-1103.2010.01248.x

Enríquez-de-Salamanca, Á., Carrasco, M. J., \& Varela, J. M. (2004). Seguimiento de la eficacia de la restauración vegetal de los taludes de autovías. Ingenieria Civil, 134, 27-36.

Enríquez-de-Salamanca, Á., Carrasco, M. J., Varela, J. M., \& Cachón, J. (2002). Seguimiento de la revegetación de taludes en infraestructuras lineales. Análisis de tres tramos de autovía en la Comunidad de Madrid. In G. Bastida (Ed.), VIII Jornadas Nacionales sobre Conservación de Carreteras (pp. 545553). ATC, Madrid.

Etxeberría, M., \& Ibáñez, R. (2005). Colonización espontánea de taludes de desmonte sobre margas en navarra: establecimiento y fuente de diásporas. Publicaciones de Biología de la Universidad de Navarra. Serie Botánica, 16, 53-70.

Fowler, J. F., Hull, C. Dickson, B. G., \& Saab, V. (2008). Exotic plant species diversity: Influence of roads and prescribed fire in Arizona ponderosa pine forests. Rangeland Ecology \& Management, 61(3), 284-293. https://doi.org/10.2111/07-059.1

García-Palacios, P., Soliveres, S., Maestre, F. T., Escudero, A., Castillo-Monroy, A. P., \& Valladares, F. (2010). Dominant plant species modulate responses to hydroseeding, irrigation and fertilization during the restoration of semiarid motorway slopes. Ecological Engineering, 36(10), 1290-1298. https://doi.org/10.1016/j.ecoleng.2010.06.005

González-Alday, J., Marrs, R. H., \& Martínez-Ruiz, C. (2009). Soil seed bank formation during early revegetation after hydroseeding in reclaimed coal wastes. Ecological Engineering, 35(7), 1062-1069.

https://doi.org/10.1016/j.ecoleng.2009.03.007

Hilvers, G., Hopkinson, L., \& Davis, E. (2017). Evaluation of revegetation techniques for roadside construction sites. Journal of Environmental Engineering and Landscape Management, 25(3), 305-315. https://doi.org/10.3846/16486897.2016.1259166

Hobbs, R. J., Higgs, E., \& Harris, J. A. (2009). Novel ecosystems: Implications for conservation and restoration. Trends in Ecology \& Evolution, 24(11), 599-605.

https://doi.org/10.1016/j.tree.2009.05.012
International Plant Name Index. (2021). IPNI. https://www.ipni. org/

Jaúregui, B. M., Rivera, D., \& Peco, B. (2013). Does topsoil accelerate the decomposition of litter on roadslopes? Ecological Engineering, 52, 88-95.

https://doi.org/10.1016/j.ecoleng.2012.12.088

Jiménez, M. D., Ruiz-Capillas, P., Mola, I., Pérez-Corona, E., Casado, M. A., \& Balaguer, L. (2013). Soil development at the roadside: A case study of a novel ecosystem. Land Degradation \& Development, 24(6), 564-574.

https://doi.org/10.1002/ldr.1157

Magro, S., Jiménez, M. D., Casado, M. A., Mola, I., Arenas, J. M., Martín-Duque, J. F., Vázquez, A., \& Balaguer, L. (2014). Community ontogeny at the roadside: Critical life-cycle events throughout a sequential process of primary colonization. Applied Vegetation Science, 17(3), 493-503.

https://doi.org/10.1111/avsc.12095

Martínez-Ruiz, C., \& Marrs, R. (2007). Some factors affecting successional change on uranium mine wastes: Insights for ecological restoration. Applied Vegetation Science, 10(3), 333-342. https://doi.org/10.1111/j.1654-109X.2007.tb00432.x

Martínez-Ruiz, C., Fernández-Santos, B., \& Gómez-Gutiérrez, J. M. (2001). Effects of substrate coarseness and exposure on plant succession in uranium-mining wastes. Plant Ecology, 155, 79-89. https://doi.org/10.1023/A:1013208305393

Martínez-Ruiz, C., Fernández-Santos, B., Putwain, P. D., \& Fernández-Gómez, M. J. (2007). Natural and man-induced revegetation on mining wastes: Changes in the floristic composition during early succession. Ecological Engineering, 30(3), 286-294. https://doi.org/10.1016/j.ecoleng.2007.01.014

Martín-Sanz, R. C., Fernández-Santos, B., Martínez-Ruiz, C. (2015). Early dynamics of natural revegetation on roadcuts of the Salamanca province (CW Spain). Ecological Engineering, 75, 223-231. https://doi.org/10.1016/j.ecoleng.2014.11.057

Matesanz, S., \& Valladares, F. (2007). Improving revegetation of gypsum slopes is not a simple matter of adding native species: Insights from a multispecies experiment. Ecological Engineering, 30(1), 67-77.

https://doi.org/10.1016/j.ecoleng.2007.01.005

Matesanz, S., Valladares, F., Tena, D., Costa-Tenorio, M., \& Bote, D. (2006). Early dynamics of plant communities on revegetated motorway slopes from southern Spain: Is hydroseeding always needed? Restoration Ecology, 14(2), 297-307. https://doi.org/10.1111/j.1526-100X.2006.00132.x

Ministerio de Transportes, Movilidad y Agenda Urbana. (2019). Mapa de tráfico de la DGC. MITMA. https://mapas.fomento. gob.es/mapatrafico/2019/

Mola, I., Jiménez, M. D., López-Jiménez, N., Casado, M. A., \& Balaguer, L. (2011). Roadside reclamation outside the revegetation season: Management options under schedule pressure. Restoration Ecology, 19(1), 83-92. https://doi.org/10.1111/j.1526-100X.2009.00547.x

Navarro-Hevia, J., Lima-Farias, T. R., Araújo, J. C., Osorio-Peláez, C., \& Pando, V. (2016). Soil erosion in steep road cut slopes in Palencia (Spain). Land Degradation \& Development, 27(2), 190-199. https://doi.org/10.1002/ldr.2459

Nicolau, J. M., Espigares, T., Moreno, M., \& Merino-Martín, L. (2011). Ecohidrología: erosión hídrica y dinámica de la vegetación en laderas artificiales. In F. Valladares, L. Balaguer, I. Mola, A. Escudero, \& V. Alfaya (Eds.), Restauración ecológica de áreas afectadas por infraestructuras de transporte. Bases científicas para soluciones técnicas (pp. 75-83). Fundación Biodiversidad. 
Raevel, V., Munoz, F., Pons, V., Renaux, A., Martin, A., \& Thompson, J. D. (2013). Changing assembly processes during a primary succession of plant communities on Mediterranean roadcuts. Journal of Plant Ecology, 6(1), 19-28. https://doi.org/10.1093/jpe/rts011

Raunkiaer, C. (1934). The life forms of plants and statistical plant geography. Oxford University Press.

Rivera, D., Mejías, V., Jaúregui, B. M., Costa-Tenorio, M., LópezArchilla, A. I., \& Peco, B. (2014). Spreading topsoil encourages ecological restoration on embankments: Soil fertility, microbial activity and vegetation cover. PLoS One, 9(7), e101413. https://doi.org/10.1371/journal.pone.0101413

Roberts, R. D., \& Bradshaw, A. D. (1985). The development of a hydraulic seeding technique for unstable sand slopes. II. Field evaluation. Journal of Applied Ecology, 2(2), 979-994. https://doi.org/10.2307/2403245

Tinsley, M. J., Simmons, M. T., \& Windhager, S. (2006). The establishment success of native versus non-native herbaceous seed mixes on a revegetated roadside in Central Texas. Ecological Engineering, 26(3), 231-240.

https://doi.org/10.1016/j.ecoleng.2005.10.004
Tormo, J., Bochet, E., \& García-Fayos, P. (2006). Is seed availability enough to ensure colonization success? An experimental study in road embankments. Ecological Engineering, 26(3), 224-230. https://doi.org/10.1016/j.ecoleng.2005.10.003

Tormo, J., Bochet, E., \& García-Fayos, P. (2007). Roadfill revegetation in semiarid Mediterranean environments. Part II: Topsoiling, species selection, and hydroseeding. Restoration Ecology, 15(1), 97-102. https://doi.org/10.1111/j.1526-100X.2006.00194.x

Tormo, J., García-Fayos, P., \& Bochet, E. (2008). Relative importance of plant traits and ecological filters in road embankment revegetation under semiarid Mediterranean conditions. Ecological Engineering, 33(3-4), 258-264. https://doi.org/10.1016/j.ecoleng.2008.05.002

Valladares, F., Balaguer, L., Mola, I., Escudero, A., \& Alfaya, V. (Eds.). (2011). Restauración ecológica de áreas afectadas por infraestructuras de transporte. Bases científicas para soluciones técnicas. Fundación Biodiversidad.

Walker, L. R., \& del Moral, R. (2009). Lessons from primary succession for restoration of severely damaged habitats. Applied Vegetation Science, 12(1), 55-67. https://doi.org/10.1111/j.1654-109X.2009.01002.x 